(b) Lithification Phase:

Stage 2 Cemented shell grit and sand lithified in dunes to form calcarenite or soft limestone. False bedding from wind layering is emphasised in lime-rich and lime-poor layers.

Stage 3 Surface solution and re-deposition in the form of kankar to form a hard consistent surface capping (capstone). Kankar also fills cavities and lines root and minor solution pipes in the underlying limestone

(c) Equilibrium Phase:

Stage 4 The kankar surface was eroded by solution to form a thinned or pinnacled surface. Deposition of secondary limestone in cavities in the underlying calcarenite.

(d) Leaching Phase:

Stage 5 The kankar was reduced to a discontinuous pinnacled layer and the calcarenite was leached with the formation of pipes and small caves. False bedding emphasised by selectively leached layers.

Stage 6 Some kankar floaters left above soft limestone masses with large collapsed cave areas and potential collapse areas.

Stage 7 Isolated kankar pinnacles left in residual quartz sand.

Stage 8 Residual quartz sand remains in place.

Progressive development of the Swan Coastal Plain of Western Australia has brought many problems and some benefits stemming from the variable nature of the Coastal Limestone Formation which is a general name for at least three generations of lithified, kankarized and leached lime sand dunes.

Case histories will be presented of the problems of development in former dune deposits, including: -
1. Problems of road and railway construction and of housing development in hard kankar (capstone) areas, which are covered by drift sands in places.

2. Problems of road, railway and housing development in karst or collapsing limestone cave areas.

3. Foundation problerns caused by isolated kankar pinnacles in residual sand.

4. Foundation problems for large structures in areas where marine erosion and leaching of calcarenite has caused large overhangs and holes.

5. Problems of dewatering limestone foundations in coastal environments.

6. Problems caused by mangrove mud held in embayments of limestone.

The environmental assets provided by kankar, calcarenite and lime and silica and include: -

1. Residual light cementation, or initial cementation, of sands provides substantial increases in bearing values.

2. Kankar is a source of high grade limestone usually $78 \%$ to $96 \%$ pure.

3. Calcarenite quarries supply foundation building blocks, easily cut with hand tools.

4. Calcarenite is the most important road-base material in the Swan Coastal Plain.

5. Marl lakes containing material residual from the leaching process are important in bitumen stabilization of roads.

6. Calcarenite is a vital auquifer in many coastal areas.

7. Calcarenite areas attenuate earthquake shock waves.

\title{
THE CHARACTER AND RECENCY OF FAULTING ALONG THE ELSINORE FAULT ZONE IN RIVERSIDE COUNTY, CALIFORNIA, U.S.A.
}

\author{
KENNEDY Michael P., Scripps Institute of Oceanography, La Jolla, California, U.S.A.
}

The Elsionore fault zone between Lake Elsinore and the Agua Tibia Mountains underlies and forms a pronounced topographic boundary between the Santa Ana Mountains and the Perris tectonic blocks. The fault zone consists of a geometrically complex group of en echelon faults that have both lateral and vertical slip components associated with them. The zone strikes northwest and is composed of the Willard, Wildomar and Wolf Valley faults. These faults form a $1-2 \mathrm{~km}$ wide graben whose approximate centre coincides with the modern drainage of Murrieta, Temecula and Wolf valleys. More than $900 \mathrm{~m}$ of Quaternary alluvium underlies the valley floor along this segment of the fault zone. Quaternary age right lateral strike-slip separation is greater than $6 \mathrm{~km}$ along the eastern side of the zone, and less than a few hundred meters along the western side. The western side is composed mostly of nearly vertical dip-slip and moderately low angle west-dipping thrust faults which together form the boundary between the Elsionore trough and the Santa Ana Mountains.

In addition to the northwest striking faults of the trough there are several divergent faults that displace Quaternary strata. The largest of these faults splay from the prominent southeasterly trend of the trough to a more easterly trend. These faults too are composed of a group of en echelon fractures that together constitute a zone of taulting. The Murrie ta Hot Springs and Lancaster faults are the most notable of this group of faults, though there are numerous other yet unnamed.

Microseismic data show the Elsionore fault zone to be active in this area $(0.5$ events per day, with magnitudes ranging between 0.4 and 2.9 on the Richter scale) but these figures are low when compared with the activity along the San Jacinto and San Andreas fault zones to the east. Only one earthquake greater than magnitude 4.5 has occurred in historic time on this segment of the Elsinore fault zone.

Displaced Holocenc alluvium attests to the youthfulness of the Elsionore fault zone. Laterally offset drainages, ponded alluvium, closed linear depressions and faceted topography mark many of the most recent traces.

A maximum and/or minimum age is assigned to each fault in the area based on the age of the rocks that are either faulted or that overiap a fault. Rocks ranging in age from Holocene to upper Miocene form a stratigraphic succession that underlies a large portion of the area. These rocks have been placed in an orderly time stratigraphic framework based on interrelationships between North American Mammal Ages, isotopic ages and superposition. 